\title{
Alternatif Tahıl: Eskinin Unutulmuş Yeni Bitkisi Tef (Eragrostis tef [Zucc.] Trotter)
}

\author{
Uğur SARI (i), İskender TİRYAKi (D) \\ Çanakkale Onsekiz Mart Üniversitesi, Ziraat Fakültesi, Tarımsal Biyoteknoloji Bölümü, Çanakkale \\ $\bowtie$ : itiryaki@comu.edu.tr
}

\begin{abstract}
ÖZET
Geçmişten günümüze değişen yaşam ve beslenme alışkanlıkları, günlük diyet içerisinde hazır gıdaların giderek daha fazla yer almasına ve her geçen gün artan sağllk sorunları tüketicilerin zaman içerisinde alternatif bitkisel besin kaynaklarını aramasına neden olmuştur. Süre gelen bu arayışlar, yeni bitki çeşitlerinin geliştirilmesine ve var olan besin kaynaklarının sağlıklı beslenme ve diyet kalite kriterleri açısından tekrar ele alınması sonucunu doğurmuştur. $\mathrm{Bu}$ arayışlar aynı zamanda geçmişi çok eskilere dayanmasına karşın, yetiştiriciliğinin farklı nedenlerle terkedildiği ya da halen dünyanın az gelişmiş, çok marjinal alanlarında geleneksel, daha ziyade ilkel tarımsal yöntemler kullanılarak üretimi yapılan bitki tür ve çeşitlerinin tekrar gündeme gelmesine neden olmuştur. Moda-bitkiler olarak da isimlendirilebilecek bu bitkiler basın ve yayın aracılığı ile tüketicilere duyurulmakta ve tüketicilerin bu bitkileri talep etmesine ve yeni pazarların oluşmasına sebep olmaktadır. Dünya genelinde insanların günlük diyetlerinin büyük bir kısmını oluşturan temel bitki tür ve çeşitleri ile kıyaslandığında, tamamen unutulmuş gibi gözüken bu bitki türlerinin yeniden keşfi, bu bitkilerin günümüzde farklı yönleri ile ele alınarak alternatif diyet ürünü olarak piyasadaki yerlerini almalarını sağlamıştır. Söz konusu moda-bitkilerden biri olan tef (Eragrostis tef) Etiyopya'nın doğal bitkisi olarak bölge insanlarının günlük diyetlerinde çok önemli bir yer tutmaktadır. Bitki son zamanlarda dünyanın farklı bölgelerinde de dengeli beslenme açısından alternatif karbonhidrat kaynağı olarak gösterilmektedir. Yeni bilimsel çalışmalar bitkinin daha fazla tanınmasına ve öneminin giderek artmasına neden olmaktadır. $\mathrm{Bu}$ çalışma, ülkemiz için önemli bir tarımsal potansiyele sahip olabilecek tef bitkisinin birçok yönü ile ele alınarak tanıtılmasını amaçlamaktadır.
\end{abstract}

\section{An Alternative Cereal: Forgotten a New Plant from The Past}

\section{ABSTRACT}

Changing lifestyles and eating habits from the past to the present, and increasing availability of ready-to-eat foods in daily diet along with increasing health problems promted consumers to look for alternative herbal nutrients over time. Such ongoing quests have led to the development of new plant varieties and the reconsidering of existing nutrients in terms of healthy nutrition and diet quality criteria. At the same time, such searches have led to the resurgence of plant species and varieties that have been produced using traditional or primitive agricultural methods in very marginal areas of the world, where cultivation has been abandoned for a variety of reasons, or which are still underdeveloped. Since such plants, which can also be called as fashion-plants, are announced to consumers by the press, those plants are demanded by the consumers and such demand creates new markets. The rediscovery of such plant species, which seem to have been completely forgotten in the past, is expected to become even more popular in the near future if they are addressed by different aspects

\section{DOI:10.18016/ ksudobil.328540}

\section{Makale Tarihçesi}

Geliş Tarihi : 14.06.2017

Kabul tarihi : 13.11.2017

Anahtar Kelimeler
Tef,
diyet,
gluten,
tahil,
beslenme

\section{Derleme Makale}

\section{Article History}

Received : 14.06.2017

Accepted : 13.11.2017

Keywords
Teff,
diet,
gluten,
cereal,
nutrition

\section{Review Article}


of today's plants, as compared to the basic plant species and varieties that make up a large part of people's daily diet around the worldwide. As a natural plant of Ethiopia, teff [Eragrostis tef (Zucc.) Trotter] is also considered as one of such fashion-plants and takes place very important role in daily diet of people of the region. The plant has recently been shown as an alternative source of carbohydrates in terms of balanced nutrition in different parts of the world. New scientific studies are causing the plant to become more recognized and to increase its importance. This study has been prepared to introduce many aspects of teff plant which may have an important agricultural potential in near future for our country.

To Cite : Sarı U, Tiryaki İ 2018. Alternatif Tahıl: Eskinin Unutulmuş Yeni Bitkisi Tef (Eragrostis teff [Zucc.] Trotter). KSÜ Tarim ve Doğa Derg 21(3). 447-456. DOI:10.18016/ ksudobil.328540

\section{Taksonomik Sinıflandırması}

Poaceae familyası, Chloridoidae (Eragrostoideae) alt familyası, Eragrostidae takımı, Eragrostis cinsine dâhil olan tef bitkisinin yaklaşık 350 türü bulunmaktadır (Watson and Macfarlane, 1992). Bu türlerden tek ve çok yıllık olanlar mevcuttur (Conert, 1992; Tefera ve ark., 2003). Geçmişte Eragrostis abyssinica (Jacq.) ve Cynodon abyssinicus (Jacq.) gibi sinonim isimler (binomial nomenclature) ile isimlendirilen bitki günümüzde Eragrostis tef (Zucc.) Trotter olarak isimlendirilmektedir (Assefa ve ark., 2011). Taksonomik sinıflandırmalardaki belirsizliklerin nedeni olarak cinsin yüksek oranda poliploidy göstermesi ve kompleks bir genom yapısına sahip olması gösterilmektedir. E. tef türünün cins içerisinde yer alan 14 yabani türden progenitör olarak yararlandığı kabul edilmektedir (Ingram ve Doyle, 2003). Cins içerisinde yer alan türlerin \%69 oranında ploidy gösterdiği bildirilmiştir. E. tef, oldukça zengin bitki topluluğuna sahip cins içerisinde tanesi için yetiştiriciliği yapılan tek tür olarak bilinmektedir. Temel kromozom sayısı 10 olan cins içerisinde diploid, tetraploid ve hexaploid genom yapllarına sahip, autove allo-poliploid yapı sergileyen çok sayıda tür bulunmaktadır (Assefa ve ark., 2011). E. tef, allotetraploid $(2 \mathrm{n}=4 \mathrm{x}=40)$ bir bitkidir (Assefa ve ark., 2011). Tef'in kültürü yapılan bitki türlerinden en yakın ilişkili olduğu bitki türü olarak ragı millet (Eleusine coracana) gösterilirken, alt familya olarak en yakın ilişkili kültür bitkileri olarak sorgum (Sorghum bicolor) ve misir (Zea mays) gösterilmektedir. Ortolog genler kullanılarak yapılan dizi analizi sonuçları ve filogenetik çalışmalar ise tef'e en yakın bitki türlerinin cin darı (Setaria italica) ve sorgum (Sorghun bicolor) olduğunu göstermiştir (Cannarozzi ve ark., 2014).

\section{Botanik Özellikleri}

Bir buğdaygil bitkisi olan tef toprak, iklim ve yetiştirme şartlarına göre değişmekle birlikte tarla şartlarında ortalama 4-8 cm arasında derinlere inebilen, morfolojik olarak zayıf saçak kök sistemine sahiptir (Assefa ve ark., 2011; Ebba, 1969). Ortalama $2.3 \mathrm{~mm}$ olan ancak 1-5 mm arasında değişebilen gövde kalınlığına sahip olan bitkide gövde boğum ve boğum aralarından meydana gelmektedir. Gövdede boğumlar dolu, boğum araları ise boştur. Gövde çoğunlukla dik gelişmekte ancak zayıf bir gövde yapısına sahip olan bitkide boylanmaya bağlı olarak yatma durumu gözlenmektedir. Bazı çeşitlerde ise yatık büyüme formu görülebilmektedir (Assefa ve ark., 2011). Bitki boyu $25 \mathrm{~cm}$ ile $135 \mathrm{~cm}$ arasında değişmektedir (Ketema, 1997; Tadesse ve Kebede, 1995). Vejetasyon süresi 90 ile 130 gün arasında değişmekte, ortalama 100 gün civarında olmaktadır (Ketema, 1993). Etyopya'daki bazı yerel çeşitlerin düşük sıcaklık ve kuraklık nedenleri ile 85 günden daha erken bir sürede olgunlaştığı bildirilmektedir (Ketema, 1993). Yapraktaki yakacık ya belirsiz ya da dumura uğramıştır. Kulakçıklar bazı genotiplerde ince tüylerden meydana gelirken diğerlerinde belirgin bir yapı sergilememektedir. Panikula şeklinde çiçek topluluğuna sahip olan bitkide salkımlar gevşek formdan sık salkım formuna kadar değişiklik göstermektedir. Salkımlarda, salkım dalları başakçıkların katlanmasına göre birincil (primer), ikincil (sekonder) ve üçüncül (tersiyer) dallar şeklinde ayrılmaktadır. Ortalama $39 \mathrm{~cm}$ olan salkım boyu, $11 \mathrm{~cm}$ ile $63 \mathrm{~cm}$ arasında değişiklik göstermektedir (Ketema, 1997). Başakcıktaki çiçek sayısı genotiplere göre değişmekle birlikte 3-17 arasındadır (Assefa ve ark., 2011). Her bir çiçek iç kavuzlar, üç erkek organ, çoğunlukla iki parçalı, istisnai durumlarda üç parçalı tüylü bir dişi organ bulunmaktadır (Ketema, 1997). Çiçeklerde tozlanma sabahın erken saatlerinde salkım tepesinden başlamakta ve maksimum 2 saat kadar devam etmektedir (Tareke, 1981). Buna karşın her başakta çiçeklenme aşağıdan yukarı doğru seyir göstermekte, bu nedenle çiçeklenme başakta 1-2 hafta, tüm salkımda ise 4 hafta kadar sürmektedir (Tareke, 1981). Panikula başına ortalama tane verimi $0.9 \mathrm{~g}$ iken bitki başına tane verimi ortalama $8 \mathrm{~g}$ civarıdır (Ketema, 1993). Her bir başakcık, uzunlukları farklı olan dış kavuzlara (Gluma) sahiptir. Tef büyük oranda 
(\% 99>) kendine tozlanan bir bitkidir (Ketema, 1993). Tozlanma günün erken saatlerinde gerçekleşmektedir. Oldukça küçük olan tef tohumları kavuzsuz, çeşit ya da hatlara göre değişmekle birlikte gelişmiş mikroskoplar altında görülebilen ağ şeklinde örülmüş liflerin meydana getirdiği düz bir tohum yüzeyine sahiptir (Kreitschitz ve ark., 2009). Tohum kabuk rengi süt beyazından koyu kahverengiye kadar değişen bitkide en yaygin tohum renkleri beyaz, süt beyazı, açık kahverengi ve koyu kahverengidir (Ketema, 1993). Tohum taneleri uzun oval biçimli olup 1.1-1.2 mm uzunluğunda ve $0.6 \mathrm{~mm}$ genişliğindedir (Kreitschitz ve ark., 2009). Tek bir tef tohumu tanesi genellikle $0.2-0.4 \mathrm{mg}$ aralığında olup bin tane ağırlığı genelde $0.19-0.21 \mathrm{~g}$ arasında değişmektedir. Ancak bazı iri taneli genotiplerde bin tane ağırlığının 0.3-0.5g arasında değiştiği rapor edilmiştir (Bedane ve ark., 2015). Bu nedenle tef tohumları karbonhidratça zengin tahıl bitkileri içerisinde en küçük tohuma sahip bitki olarak gösterilmektedir (Belay ve ark., 2006; Bultosa, 2007). Bitki tanelerinin yere düşürülmesi durumunda kolayca kaybolması ve bulunmasinın neredeyse imkânsız olması nedeniyle yerel dilde bu bitki (Amharca Etiyopya'nın millî resmî dili) teffa (kayı) olarak isimlendirilmektedir.

\section{Yetiştirilmesi Sıcaklık, Yağış ve Toprak İsteği}

Tropik ve subtropik iklim bölgelerinin bitkisi olan tef her iki yarım kürede de yayılım göstermektedir. Deniz seviyesinden $2800 \mathrm{~m}$ rakımlara kadar farklı topografyalarda yetişebilen bitki en iyi gelişimini 1800-2100m rakımlarda göstermektedir (Evert ve ark., 2009; Miller, 2010). Tef toprak sicaklığının minimum $19^{\circ} \mathrm{C}$ olduğu durumlarda iyi bir çimlenme ve büyüme göstermektedir (Evert ve ark., 2009). Yıllık yağışı $750-800 \mathrm{~mm}$, vejetasyon döneminde 450-550 $\mathrm{mm}$ yağı rejimlerine sahip bölgelerde en iyi gelişim göstermektedir. Tek yıllık sıcak iklim bitkisi olan tef diğer sıcak iklim bitkilerinin yetiştirilebildiği iklim koşulları altında ekimi yapılabilmektedir (Miller, 2010). Tef diğer tahıllar ile karşılaştırıldığında çok farklı iklim ve toprak şartlarına adapte olabildiği görülmektedir (Bekele ve ark., 1995; Jackman, 1999; Ketema, 1997). Genelde iyi drene olmuş ağır bünyeli killi, yüksek rakımlı Etiyopya topraklarına iyi adapte olduğu bildirilmiştir. Ancak, günümüzde çok daha geniş iklim ve özellikle marjinal toprak koşullarında yetiştiriciliği yapılmaktadır. Bitki genel olarak kuraklık ve su basmalarına karşı toleranttır. Fakat kuru ve uzun süreli yağışlardan kaynaklı su basmalarına karşı iyi bir bitki örtüsü oluşturamaz. Çok farklı iklim ve toprak şartlarında yetiştirilebilmesi nedeni ile Amerika'nın Idoha eyaletinin kurak ve rakımı yüksek dağları yanında Kuzey İrlanda'nın islak, taban suyu yüksek topraklarına kadar çok farklı toprak ve iklim şartlarında tarımının yapılabilmesi mümkün olmaktadır (Crymes, 2015). Küçük tohumları nedeni ile çok iyi hazırlanmış toprak hazırlığı gerektiren bitki, toprak yapısı, yabancı ot durumu ve drenaj sorunlarına göre 2-5 kez sürülerek iyi hazırlanmış tohum yatağı hazırlığ gerektirmektedir. Ekimi drenaj sorunu olan yerlerde tohum yatağ s sirtlarına el ya da makine ile yapılabilmektedir. Çok küçük tohumlu olan tef bitkisinin ekimi genelde toprak yüzeyine yapılmaktadır. Diğer taraftan ekim derinlikleri ile yapılan bir çalışmada yüzeysel yapılan ekimlerde, 5-20 mm ekim derinliklerine göre çıkış oranlarında önemli azalmalar olduğu tespit edilmiştir (Debelo, 1992). Bu nedenle tohum ekiminde toprak-tohum temasinı artıracak baskılama işleminin yapılması iyi bir tohum çimlenmesi ve iyi bir bitki örtüsünün oluşması için önemlidir. Ekim için kaplanmış tef tohumlarının kullanılması ekim derinliği ve birim alandaki bitki sayısını kontrol edebilmek açısından tavsiye edilmektedir. Elle yapılacak ekimde homojen tohum dağılımına sağlamak daha güç olduğu için $5.5 \mathrm{~kg} / \mathrm{da}$ kadar tohum yeterli olmakla birlikte, makinalı ekimde bu oran $1.5 \mathrm{~kg} / \mathrm{da}$ ' a kadar düşebilmektedir.

\section{Gübreleme İsteği}

Tef düşük girdili bir ürün olarak göz önüne alındığından minimal gübreleme ihtiyacı duymaktadır. Bu nedenle çok farklı iklim ve toprak şartlarına adapte olabilen bitkinin gerçek gübreleme değerleri, yetiştirildiği toprak şartlarına göre yapılacak denemeler ile belirlenmesi gerekmektedir. Ancak, genelde dekara 4-6 kg N ve 2-3 $\mathrm{kg} \mathrm{P}_{2} \mathrm{O}_{5}$ tef yetiştiriciliği için yeterli olmaktadır. Azot gübrelemesinin bölünerek verilmesinin tane verimini artırdığı, sap verimine ise herhangi bir etkisinin olmadığ 1 belirtilmiştir (Alkamper, 1973). Tef üretiminde potasyum $(\mathrm{K})$ gübrelemesinin hiç ya da çok az öneme sahip olduğu rapor edilmiştir (Alkamper, 1973). Yonca gibi baklagillerden sonra yapılacak tef yetiştiriciliğinde ekstra azotlu gübreye uygulamasına ihtiyaç duyulmamaktadır (Miller, 2010). Ayrica, yüksek azot uygulamasından kaynaklanan ve diğer sicak mevsim buğdaygillerinde gözlenen nitrat toksitesi tef bitkisi için henüz rapor edilmemiştir.

\section{Yabancı Ot Kontrolü}

Tef ekimi uygun sezonda, yeterli sıklıkla ve gerekli aletlerle yabancı otlardan arı hale getirilmiş tarlaya yapılmalıdır (Ketema, 1997). Ekilecek tohumların saf ve yabancs ot tohumlarından ari olması, ekim sonrasında yapılacak yabancı ot mücadelesi için çok önemli katkı sağlamaktadır (Ketema, 1997). Sıcak ortam şartlarında daha hızlı çimlenebilen tef tohumları, çıkış sonrası ilk iki haftalık dönemde toprak üstü aksam yerine kök sisteminin geliştirilmesine yönelik büyüme davranışı sergilemektedir. $\mathrm{Bu}$ nedenle erken vejetasyon 
döneminde, diğer bir deyişle bitkinin toprak üstü aksamının aktif büyümeye geçeceği evreye kadar olan dönemde yabancı ot rekabetinin azaltılması, uygun yabancı ot mücadelesinin yapılmasinı gerektirmektedir. Mevsiminin erken zamanlarında, sinırlı toprak işleme tekniklerinin kullanıldığ tarlalarda daha fazla yabancı ot problemleri ile karşılaşılabilmektedir. Yabancı ot baskısını azaltmak amacıyla tef ekiminin, toprak sicaklığının arttığ dönemlerde yapılması tavsiye edilmektedir (Miller, 2010). Yabancı ot oranının az olduğu yerlerde, çıkıştan 25-30 gün sonra mekanik olarak yapılacak yabancı ot mücadelesi yeterli olmaktadır. Ancak, yabancı ot oranının fazla olduğu alanlarda sapa kalkmadan önceki bir dönemde ikinci bir yabancı ot mücadelesi tavsiye edilmektedir. Buna karşılık sapa kalkma sonrası bitkiye büyük zararlar vermesi nedeniyle yabancı ot mücadelesinin yapılmaması gerekmektedir (Ketema, 1997). Yabancı ot rekabeti tef tarımında \%52'lere varan verim kayılarina neden olabilmektedir (Berhanu, 1986). Mekanik yabancı ot mücadelesine karşın yabancı ot ilaçlarının ekimden 12 hafta önce özellikle geniş yapraklı tek yıllık yabancı ot mücadelesinde etkin olduğu belirtilmiştir (Berhanu, 1986). Kardeşlenme döneminde 4-chloro-2-butynyl3chlorocarbanilate ve benzer etken madde içerikli yabancı ot ilaçlarının başarıyla kullanılabileceği belirtilmiştir (Berhanu, 1986; Ketema, 1993). Tef bitkisinin herbisitlerin 2,4-D içerikli olanlarına karşı kısmen toksik etki gösterdiği, Glyphosate, terbutryne ve primagram gibi ilaçların ise doğrudan toksik etkiye sahip oldukları rapor edilmiştir (Ketema, 1993).

\section{Hastalık ve Zararlılar}

Tef diğer tahıllarla karşılaştırıldığında gerek bitki ve gerekse tane olarak bitki hastalıklarına karşı kısmen tolerant olarak kabul edilmektedir (Cheverton and Chapman, 1989; Stallknecht ve ark., 1993). Tef yetiştirilen bölgelerde 33 çeşit mantar ve nematod kaynaklı hastalık tespit edilmiştir (Refera, 2001). En önemli tef hastalıklarının ise pas (Uromyces eragrostidisy) ve salkım yanıklığı (Helminthosporium miyakei Nisikado) olduğu, nemin yüksek seviyede olduğu bölgelerde ise bu hastalıkların daha büyük zararlara neden olabileceği rapor edilmiştir (Cheverton ve Chapman, 1989; Stewart ve Yiroou, 1967; Tareke, 1981). Diğer taraftan, pas hastalığ bitkide \%10-25 oranlarında kayıplara neden olurken tane veriminde önemli bir verim kaybının meydana gelmediği, söz konusu durumun tane amaçlı yapılacak yetiştiricilik açısından büyük bir avantaja sahip olabileceği bildirilmektedir (Ketema, 1993). Fide çökerten hastalığına sebep olan Drechslera poae (Baudis) bitki sıklığının fazla olduğu alanlar ile geç ekim yapılan alanlarda önemli verim kayıplarına neden olabileceği belirtilmiştir (Ketema, 1997).
Tef bitkisine değişik oranlarda zarar veren çok sayıda zararlının var olduğu rapor edilmiştir (Ketema, 1993). Ancak bunlardan kırmızı tef kurdu (Mentaxya ignicollis) larva ve erginlerinin yaprak ve erken olum dönemindeki tanelere çok önemli zararlar verdiği tespit edilmiştir (Gebremedhin, 1987). Bu zararliya karşı uygun zamanda (metrekarede 25> larva) yapılacak tek seferlik ilaç uygulamasının yeterli olacağl, bu uygulama sayesinde önemli verim kayıplarının ortadan kaldırılabileceği bildirilmiştir.

\section{Yem Bitkisi Olarak Tef}

Tef daha ziyade tanesi için yetiştirilen ve bu şekilde bilinen bir bitki olmasına karşın bitkinin yem bitkisi olarak kullanılma potansiyeli oldukça yüksektir. Özellikle Güney Afrika ve Amerika'da yapılan çalışmalar bitkinin yem bitkisi olarak değerlendirilebileceğini göstermiştir. Tef otunun besleyici ve hayvanlar tarafindan sevilerek tüketildiği, yaprak/sap oranının (73/27) oldukça yüksek olduğu ve otunun \%65 oranında sindirilebildiği rapor edilmiştir (National Academy of Sciences 1996). Tef bitkisinin yem kalite kriterleri açısından diğer bazı yem bitkileri ve tahıllar ile olan karşılaştırmasına ait veriler Çizelge 1'de sunulmuştur. Ham protein oranı mısır ile yulaf arasında yer alan bitkide selüloz oranı diğer tahıllardan belirgin bir şekilde yüksektir (Çizelge 1). NDF oranı, karşılaştırıldıkları diğer tahıllardan daha yüksek olurken ADF oranı yonca otuna diğer tahıllardan daha yakındır (Tablo 1). Bakım ve gübreleme işlemi olması gerektiği şekilde yapılan ve çiçeklenme öncesi dönemde hasat edilen tef otunda \%13-16 civarında bulunan ham protein, tohum bağlama döneminde \%6.5’lara gerilemektedir (Kaplan ve ark., 2016). Tef samaninda \%3.6 oranında ham protein bulunmakta, protein oranı erken çiçeklenme döneminde $121 \mathrm{~g} \mathrm{~kg}^{-1}$, tam çiçeklenme döneminde ise $86 \mathrm{~kg}^{-1}$ arasında değişebilmektedir (Çizelge 1) (Mosi and Butterworth, 1985). Uygun iklim ve toprak şartlarında ekimden ilk biçime kadar geçen süre 50-55 gün olurken birinci biçimden itibaren ikinci biçime kadar geçen süre 40-45 gün olarak belirtilmektedir (Roseberg ve ark., 2005). Biçim sonrası büyümenin hızlı olduğu bitkide biçim yüksekliğinin en az 8-12 cm yüksekten yapılması tavsiye edilmektedir (Roseberg ve ark., 2005). Ancak, bitkinin zayıf kök yapısı biçim sırasında bitkinin tamamen topraktan sökülmesine neden olabileceğinden dolayı bitkinin biçilerek değerlendirilme potansiyelinin araştırılması gerekmektedir. Tef özellikle diğer sıcak iklim yem bitkileri olan millet, sorgum, sorgum-sudan otu melezi gibi bitkiler ile karşılaştırıldığında, ince-narin gövde yapısı ve bol yapraklı olması nedenleri ile hayvan beslenmesi açısından birincil derecede ot amaçlı kullanılabileceğini, ancak silaj bitkisi olarak kullanılabilme potansiyelinin var olduğu ve araştırılması gerektiği düşünülmektedir. 
Çizelge 1.Tef bitkisinin yem kalite kriterleri açısından diğer bazı yem bitkileri ve tahıllar ile olan karşılaştırması (Mosi ve Butterworth, 1985'dan uyarlanmıştır).

\begin{tabular}{lrrrrr}
\hline Bileşenler* & $\begin{array}{r}\text { Yonca } \\
\text { kuru ot }\end{array}$ & $\begin{array}{r}\text { Misır } \\
\text { Koçanı }\end{array}$ & $\begin{array}{r}\text { Yulaf } \\
\text { Samanı }\end{array}$ & $\begin{array}{r}\text { Tef } \\
\text { Samanı }\end{array}$ & $\begin{array}{r}\text { Buğday } \\
\text { Samanı }\end{array}$ \\
\hline \hline Kuru Madde (\%) & 90.1 & 91.0 & 91.9 & 91.1 & 92.4 \\
Organik madde & 89.5 & 88.2 & 91.9 & 90.8 & 89.5 \\
Ham protein & 20.1 & 5.1 & 6.2 & 3.6 & 2.3 \\
Nötral Deterjan Selülozu & 44.4 & 75.5 & 71.2 & 77.5 & 76.1 \\
Asit Deterjan Selülozu & 36.6 & 51.3 & 46.6 & 44.3 & 51.7 \\
Lignin (Odun Özü) & 4.8 & 4.8 & 6.6 & 5.1 & 6.4 \\
Hemi-selüloz & 7.8 & 24.2 & 24.6 & 33.3 & 24.3 \\
Selüloz & 31.8 & 46.5 & 40.0 & 39.2 & 45.3 \\
ADF-kül & & 5.2 & 3.6 & 3.4 & 6.9 \\
Fosfor & 0.30 & 0.17 & 0.15 & 0.25 & 0.22 \\
Metabolik enerji (Mj/kg") & 19.0 & 16.7 & 17.9 & 17.6 & 18.8 \\
\hline
\end{tabular}

${ }^{*} \mathrm{~kg} \mathrm{da}{ }^{-1}$

Diğer taraftan özellikle mera bitkilerinin yaz periyodu boyunca verim yanında önemli kalite kayıplarına uğraması bu alanlarda alternatif bitkilerin ele alınmasını gerektirmektedir. Bu alanlarda yağış ve iklim şartlarının normal olması durumunda çok yıllık serin iklim yem bitkileri yüksek kalitede ürün vermelerine karşın, özellikle kuru ve yüksek sıcaklığa sahip iklim koşullarında ve özellikle de yaz aylarının ikinci yarısından sonra çok önemli verim ve kalite kayıplarına uğramaktadır. Bu nedenle sıcak iklim şartlarında, kurağa tolerant olan tek yıllık tef bitkisi bu alanlarda yetiştirilecebilecek önemli bir alternatif yem bitkisi olarak öne çıkmaktadır (Hunter ve ark., 2007).

\section{Kimyasal Kompozisyonu}

Tahıl ürünlerinin kimyasal kompozisyonu tahıl türüne göre büyük çapta degişiklik göstermektedir. $\mathrm{Bu}$ değişim aynı zamanda yetiştirme şartları, iklim ve toprak özellikleri ile gübreleme ve sulama gibi kültürel uygulamalara da bağlı olarak değişmektedir (Baye, 2014). Tef bitkisini buğday, arpa ve çavdar gibi diğer tahıl ürünleriden ayıran ve öne çıkmasını sağlayan en önemli özelliği gluten içermemesidir (Baye, 2014). Glutensiz gıdalara olan talep, çölyak hastalığı tanısı ve diğer glutene hassas hastalıkların artışına bağlı olarak her geçen gün daha da artmaktadır (Bultosa ve Taylor, 2004; Hopman ve ark., 2008). Tahillar, insan beslenmesinde karbonhidrat ve ana enerji kaynağ 1 olduğu kadar aynı zamanda metabolizma ve hücre dengesi için de önemli bir yere sahiptir (Baye, 2014). Tef tohumlarmin \%73.1'i kompleks karbonhidratlardan oluşmaktadır (USDA, 2016) (Çizelge 2). Besinlerdeki karbonhidratların parçalanma oranı glisemik indeks (GI) ile karakterize edilmektedir (Harris ve Geor, 2009). Gidaların glisemik indeksi gida matrisinin endojen faktörlerine bağlı olup bunlar alfa-amilaza (Nişasta) duyarlılık, protein, yağ içeriği ve gıdanın makroskobik yapısına bağlı kalmaktadır (Fardet ve ark., 2006). Tef'in glisemik indeksi 74 ile buğdaydan (beyaz) önemli derecede düşük iken sorgum ve çavdar ile benzerlik göstermektedir (Wolter ve ark., 2013). Aminoasit bileşimi bakımından dengelenmis bir yapı sergileyen tanedeki ham protein miktarının diğer tahıllara göre daha yüksek olduğu $(13.3 \mathrm{~g} / 100 \mathrm{~g})$ rapor edilmiştir (Çizelge 2) (Baye, 2014). Tef tohumlarının ham yağ içeriği buğday arpa ve çavdar gibi gluten içeren tahıllardan daha yüksek olmasına karşın ham yağ oranı glutensiz tahıllardan olan mısır, çeltik ve sorgumdan daha düsüktür (Çizelge 2). Ayrıca, tef tohumları insan beslenmesi için önemli olan esansiyel doymamış yağ asitleri bakımından da zengindir (Gebremariam ve ark., 2012). Diğer taraftan tef tohumları, bira üretiminde çok önemli olan yüksek ham lif oranı $(8 \mathrm{~g} / 100 \mathrm{~g})$ ile glutensiz diğer tahıllar arasında dikkat çekmektedir (Çizelge 2). Çoğu glutensiz gıdalar nişastalarla veya rafine edilmiş unlarla tüketildiğinde muhtemelen yetersiz lif alıminına sebep olabilmektedir (Thompson, 2000). Bunun en önemli nedeni rafine işlemleri sırasında lif oranı yüksek meyve ve tohum kabuğu (karyopsis) kısmının tohumdan ayrılarak geriye nişasta oranı yüksek un elde edilmesidir. Buna karşın çok küçük olan tef tohumları herhangi bir rafine işlemine tabi tutulmadan tam tahıl olarak (karyopsis, endosperm ve embriyo) doğrudan kullanılabilmektedir. Bu yüzden diğer tahıllar kullanılarak hazırlanan besinlerle karşılaştırıldığında, içeriğinde tef bulunan gidaların yüksek lif ve besin içeriğine sahip olduğu gözükmektedir (Vinning ve McMahon, 2006). 
Çizelge 2. Tef (Eragrostis tef) bitkisinin diğer glutensiz ve glutence zengin tahıl bitkileriyle besin bileşenleri açısından karşılaştırılması (USDA, 2016)'dan alıntılanmıştır.

Glutensiz Tahıllar

Glutence Zengin Tahıllar

\begin{tabular}{lrrrrrrr}
\hline \hline $\begin{array}{l}\text { Bileşen Değerleri } \\
\text { (gram / 100 gram) }\end{array}$ & Tef & Misır & Çeltik & Sorgum & Buğday & Arpa & Çavdar \\
\hline \hline Su & 8.8 & 10.4 & 9.4 & 12.4 & 13.1 & 9.6 & 10.6 \\
Enerji (kcal) & 367.0 & 365.0 & 354.0 & 329.0 & 327.0 & 342.0 & 338.0 \\
Protein & 13.3 & 9.4 & 7.5 & 10.6 & 12.6 & 12.5 & 10.3 \\
Karbonhidrat & 73.1 & 74.3 & 76.3 & 72.1 & 71.2 & 73.5 & 75.9 \\
Toplam yağ & 2.4 & 4.7 & 3.2 & 3.5 & 1.5 & 2.3 & 1.6 \\
Ham Lif & 8.0 & 7.3 & 3.6 & 6.7 & 12.2 & 17.3 & 15.1 \\
SSeker & 1.8 & 0.6 & 0.7 & 2.5 & 0.4 & 0.8 & 1.0 \\
\hline
\end{tabular}

\section{Amino asit kompozisyonu}

Tef tohumları besin değerleri açısından buğday ile benzerlik göstermekle beraber Amerika Ulusal Bilimler Akademisi'ne (National Academy of Sciences, 1996) göre buğdaydan daha besleyici ve içerik olarak temel amino asit miktarı bakımından daha değerlidir (Çizelge 3). Jansen ve ark. (1962)'nın araştırma bulgularına göre, tef'in gerekli amino asitler açısından mükemmel bir dengeye sahip olduğunu ve bunun yumurta ile karşılaştırılabileceği rapor edilmiştir (Jansen ve ark., 1962). Çizelge 3'de tef'in amino asit kompozisyonu bakımından mükemmel bir içeriğe sahip olduğu, bu nedenle genel amino asit çeşitliliği bakımından diğer tahıllar ile kıyaslandığında dengeli bir yapı sergilediği Kabul edilmektedir. Özellikle, lizin içeriğinin arpa ile beraber diğer hububatlara kiyasla daha yüksek olduğu, izolizin, serin, valin, tirosin, treonin, metiyonin, fenilalanin, alanine, aspartik asit ve histidin içeriğinin ise arpa, buğday ve diğer pek çok tahıldan daha yüksek olduğu görülmektedir. Tef tohumlarının bu içeriği, alkollü içecekler için önemli kriterlerden biri olan stabilite özelliklerinin yüksek olduğunu göstermektedir (Gebremariam ve ark., 2012).

Çizelge 3. Tef (Eragrostis tef) bitkisinin diğer glutensiz ve glutence zengin tahıl bitkileriyle amino asit içerikleri açısından karşılaştırılması (USDA, 2016)'dan uyarlanmıştır.

\begin{tabular}{lllllllc}
\hline & \multicolumn{4}{c}{ Glutensiz Tahıllar } & \multicolumn{3}{c}{ Glutence Zengin Tahıllar } \\
\hline $\begin{array}{l}\text { Aminoasit } \\
\text { (gram/100 gram) }\end{array}$ & Tef & Misir & Çeltik & Sorgum & Buğday & Arpa & Çavdar \\
\hline \hline Triptofan & 0.14 & 0.07 & 0.10 & 0.12 & 0.16 & 0.21 & 0.11 \\
Treonin & 0.51 & 0.35 & 0.29 & 0.35 & 0.37 & 0.42 & 0.29 \\
Izolösin & 0.50 & 0.34 & 0.34 & 0.43 & 0.46 & 0.46 & 0.21 \\
Lösin & 1.07 & 1.16 & 0.66 & 1.49 & 0.85 & 0.85 & 0.56 \\
Lizin & 0.38 & 0.27 & 0.30 & 0.23 & 0.34 & 0.47 & 0.29 \\
Metiyonin & 0.43 & 0.20 & 0.18 & 0.17 & 0.20 & 0.24 & 0.15 \\
Sistein & 0.24 & 0.17 & 0.10 & 0.13 & 0.32 & 0.28 & - \\
Fenilalanin & 0.70 & 0.46 & 0.41 & 0.55 & 0.59 & 0.70 & 0.44 \\
Tirozin & 0.46 & 0.38 & 0.30 & 0.32 & 0.39 & 0.36 & 0.20 \\
Valin & 0.69 & 0.48 & 0.47 & 0.56 & 0.56 & 0.61 & 0.32 \\
Arjinin & 0.52 & 0.47 & 0.60 & 0.36 & 0.60 & 0.63 & 0.45 \\
Histidin & 0.30 & 0.29 & 0.20 & 0.25 & 0.29 & 0.28 & 0.19 \\
Alanin & 0.75 & 0.71 & 0.46 & 1.03 & 0.45 & 0.49 & 0.41 \\
Aspartik asit & 0.82 & 0.66 & 0.74 & 0.74 & 0.64 & 0.78 & 0.56 \\
Glütamik asit & 3.34 & 1.77 & 1.62 & 2.44 & 4.00 & 3.26 & 2.29 \\
Glisin & 0.48 & 0.39 & 0.39 & 0.35 & 0.53 & 0.45 & 0.42 \\
Prolin & 0.66 & 0.82 & 0.37 & 0.85 & 1.29 & 1.48 & 0.80 \\
Serin & 0.62 & 0.45 & 0.41 & 0.46 & 0.59 & 0.53 & 0.46 \\
\hline
\end{tabular}


Çizelge 4. Tef (Eragrostis tef) bitkisinin diğer glutensiz ve glutence zengin tahıl bitkileriyle mineral içerikleri açısından karşılaştırılması (USDA, 2016)'dan uyarlanmıştır.

Glutensiz Tahıllar Glutence Zengin Tahıllar

\begin{tabular}{lrrrrrrr}
\hline \hline $\begin{array}{l}\text { Mineral Değerleri } \\
\text { (miligram/ 100 gram) }\end{array}$ & Tef & Misır & Çeltik & Sorgum & Buğday & Arpa & Çavdar \\
\hline \hline Kalsiyum (Ca) & 180.0 & 7.0 & 9.0 & 130.0 & 29.0 & 33.0 & 24.0 \\
Demir (Fe) & 7.6 & 2.7 & 1.3 & 3.4 & 3.2 & 3.6 & 2.6 \\
Magnezyum (Mg) & 184.0 & 127.0 & 116.0 & 165.0 & 126.0 & 133.0 & 110.0 \\
Fosfor (P) & 429.0 & 210.0 & 311.0 & 289.0 & 288.0 & 264.0 & 332.0 \\
Potasyum (K) & 427.0 & 287.0 & 250.0 & 363.0 & 363.0 & 452.0 & 510.0 \\
Sodyum (Na) & 12.0 & 35.0 & 5.0 & 2.0 & 2.0 & 12.0 & 2.0 \\
Cinko (Zn) & 3.6 & 2.2 & 2.1 & 1.7 & 2.7 & 2.8 & 2.7 \\
Bakir (Cu) & 0.8 & 0.3 & 0.3 & 0.3 & 0.4 & 0.5 & 0.4 \\
Mangan (Mn) & 9.2 & 0.5 & 2.9 & 1.6 & 4.0 & 1.9 & 2.6 \\
Selenyum (Se) & 4.4 & 15.5 & 17.1 & 12.2 & 70.7 & 37.7 & 13.9 \\
\hline
\end{tabular}

*, mikrogram / 100 gram.

\section{Mineral İçeriği}

Araştırma verileri, tef tahıllarının mineral içeriklerinin, bazı durumlarda buğday, arpa ve diğer pek çok hububattan daha yüksek olduğunu göstermektedir (Çizelge 4). Genel olarak diğer tahıllarla karşılaştırıldığında tef kalsiyum, çinko, magnezyum, demir, fosfor ve bakır gibi mineraller bakımından zengindir (Bultosa ve Taylor, 2004; Ketema, 1997). Kalsiyum vücudumuzdaki en yaygın minerallerden biri olup iskelet ve diş sağlığı açısından büyük bir öneme sahiptir. Yüksek kalsiyum içeren diyetler kilo alımı ve yağ birikimini önlemesi nedenleri ile her geçen gün önemini arıtmaktadır (Teegarden, 2003; Zemel, 2003). Diğer tahıllar ile kıyaslandığında tef bitkisinin kalsiyum oranının mükemmel bir değere sahip olduğu görülmektedir (Çizelge 4). Bu nedenle, tef bitkisinin günlük diyetlere dahil edilmesi az kalsiyum tüketimi sonucu oluşabilecek sağlık sorunlarının giderilmesinde önemli bir yer teşkil edecektir (Çizelge 4). Diğer taraftan demir eksikliği küresel olarak en yaygın görülen mikrobesin eksikliklerinden biri olup 2 milyardan daha fazla insanı etkilediği bildirilmektedir (Zimmermann ve Hurrell, 2007). Büyüme geriliği, bozulmuş zihinsel ve psikomotor gelişimi, çocuk ve anne ölümleri ile azalmış bağışıklık ve iş performansı, demir eksikliğinin olumsuz etkilerinden bazılarıdır (Georgie, 2011). Diğer temel tahıllar ile kıyaslandığında daha yüksek demir oranına sahip olan tef bitkisi, lokal ya da küresel boyutta demir eksikliğinin giderilmesinde önemli bir alternatif bitki olarak görülmektedir (Çizelge 4). Nitekim, Alaunyte ve ark. (2012), \%30 tef unu içeren buğday ekmeğinde demir içeriğinin iki kattan daha fazla oranda arttığını tespit etmişlerdir (Alaunyte ve ark., 2012). Ayrıca, ortalama günlük 200 gr tefce zengin ekmek tüketildiğinde, kadınlar ve erkekler için günlük demir ihtiyacının sirasiyla \% 42-81 ve \%72-138'nin karşlanabileceği belirtilmiştir (Alaunyte ve ark., 2012).

\section{Vitamin İçeriği}

Vitaminler, kalp problemleri, yüksek kolesterol seviyeleri, göz rahatsızlıkları ve cilt bozuklukları gibi çeşitli hastalıkları önlemek ve tedavi etmek için gereklidir. Vitaminlerin çoğu vücut mekanizmasını düzenler ve başka hiç bir besin tarafından uygulanmayan işlevleri yerine getirir (WHO, 2003). Tef, her 100 gramda kolin (13.1 mg), niyasin (B3) (3.4 $\mathrm{mg}$ ), A vitamini $(9 \mathrm{mg})$, riboflavin (B2) $(0.3 \mathrm{mg})$, tiyamin (B1) $(0.4 \mathrm{mg})$ ve gama tokoferol $(5 \mathrm{mg})$ gibi vitaminleri yüksek seviyelerde içeren önemli bir tahıldır (Çizelge 5). Bu nedenle vitamin içeriği artırılmış gıdaların üretilmesinde ve geliştirilmesinde tef önemli bir alternatif bitki olarak gözükmektedir.

\section{SONUÇ}

Tef, diğer tahıllarla kıyaslandığında bir kaç bitki hastalığı ve depo zararlıları dışında hastalık ve zararlılardan etkilenmeden büyüme ve gelişmesini sürdürebilen, yüksek nem ve olası kuraklık stresi gibi abiyotik stress faktörlerinden etkilenmeden çok farklı ekolojilere adapte olabilen, eskinin unutulmuş yeni bitkisi olarak son zamanlarda dikkat çekmekte ve önemini her geçen gün artırmaktadır. Yetiştiricilik açısından düşük riskli bir tahıl olarak görülen bitki hububat grubu içerisinde dünyanın en küçük tohumuna sahip olup, yavaş sindirilebilen nişasta yapısı ile kompleks karbonhidratlardan oluşmaktadır. 
Çizelge 5. Tef (Eragrostis tef) bitkisinin diğer glutensiz ve glutence zengin tahıl bitkileriyle vitamin içerikleri açısından karşılaştırılması (USDA, 2016)'dan uyarlanmıştır.
Glutensiz
Tahillar
Glutence Zengin Tahıllar

\begin{tabular}{lrrrrrrr}
\hline \hline $\begin{array}{l}\text { Vitamin Değerleri } \\
\text { (milligram/ 100 gram) }\end{array}$ & Tef & Misır & Çeltik & Sorgum & Buğday & Arpa & Çavdar \\
\hline \hline Tiyamin (B1) & 0.4 & 0.4 & 0.5 & 0.3 & 0.4 & 0.6 & 0.3 \\
Riboflavin (B2) & 0.3 & 0.2 & 0.1 & 0.1 & 0.1 & 0.3 & 0.3 \\
Pantotenik asid (B5) & 0.9 & 0.4 & 1.1 & 0.4 & 1.0 & 0.3 & 1.5 \\
Niyasin (B3) & 3.4 & 3.6 & 6.5 & 3.7 & 5.5 & 4.6 & 4.3 \\
Vitamin B-6 & 0.9 & 0.6 & 0.5 & 0.4 & 0.3 & 0.32 & 0.29 \\
Kolin Vitamin & 13.1 & - & 21.5 & - & 31.2 & & 30.4 \\
Betain & 2.3 & - & - & - & - & - & 146.1 \\
Beta Karoten & 5.0 & 97.0 & - & - & 5.0 & 13.0 & 7.0 \\
A Vitamini , IU & 9.0 & 214.0 & - & - & 9.0 & 22.0 & 11.0 \\
Lütein + Zeaksantin* & 66.0 & 1355.0 & - & - & 220.0 & 160.0 & 210.0 \\
Vitamin E & 0.1 & 0.5 & 0.6 & 0.5 & 1.0 & 0.6 & 0.9 \\
Tokoferol, gamma & 5.0 & - & 0.2 & - & - & - & - \\
Vitamin K * & 1.9 & 0.3 & 0.6 & - & 1.9 & 2.20 & 5.9 \\
\hline
\end{tabular}

*, mikrogram/100gram.

Diğer hububatlar ile kıyaslandığında benzer bir protein içeriğine sahip olan bitkinin en önemli özelliği gluten içermemesidir. Dengelenmiş bir amino asit kompozisyonuna sahip olan bitki esansiyel amino asitler ve yă̆ asitleri, lif, mineraller (özellikle kalsiyum ve demir) ile polifenoller ve fitatlar gibi fitokimyasal maddelerce zengin bir besin kaynağ olarak gösterilmektedir. Bitki aynı zamanda hayvancılık açısından yaz ortasında ihtiyaç duyulan yeşil kaba yemin karşılanmasında çok önemli bir potansiyele sahip bulunmaktadır. Bitkinin sahip olduğu tüm avantaj ve kullanım potansiyellerine karşın tef tüketimi dünya genelinde Etiyopya ile sınırlı kalmıştır. Bunun temel nedeni olarak, yakın zamana kadar literatürde tef'in besin kompozisyonu ile ilgili sınırlı bilginin bulunması ve tef içeren gida ürünlerinin uluslararası tüketicilere uyarlamada karşılaşılan zorluklar gösterilmektedir. Ancak, son zamanlarda sağlıklı gida hammaddesine olan talebin artması tef'e olan ilgiliyi artırmıştır. Bu nedenle tef, özellikle ülkemiz gibi günlük diyetde yüksek oranda karbonhidrat tüketen toplumların sağlıklı beslenme ihtiyaçlarının karşılanmasında önemli bir alternatif bitki olarak görülmektedir. Tef bitkisinin ülkemiz için olası potansiyelleri göz önüne alındığında, bu çalışmanın ülkemizde yapılacak yeni bilimsel çalışmalara ışık tutması beklenmektedir.

\section{KAYNAKÇA}

Alaunyte I, Stojceska V, Plunkett A, Ainsworth P, Derbyshire E. 2012. Improving the quality of nutrient-rich Teff (Eragrostis tef) breads by combination of enzymes in straight dough and sourdough breadmaking. Journal of Cereal Science, 55(1):22-30.
Alkamper J. 1973. The fertilization of teff. J. Assoc. Adv. Agric. Sci. Africa 1: 56-65.

Assefa K, Yu JK, Zeid M, Belay G, Tefera H, Sorrells ME. 2011. Breeding tef [Eragrostis tef (Zucc.) trotter]: Conventional and molecular approaches. Plant Breeding, 130: 1-9.

Baye, K. 2014. Synopsis:Teff: nutrient composition and health benefits. ESSP Research Note 34 . Washington, D.C.

Bedane GM, Saukuru AM, George DL, Gupta ML. 2015. Evaluation of teff (Eragrostis tef [Zucc.] Trotter) lines for agronomic traits in Australia. Australian Journal of Crop Science, 9: 242-247.

Bekele E, Fido RJ, Tatham AS, Shewry PR. 1995. Heterogeneity and Polymorphism of Seed Proteins in Tef (Eragrotis Tef). Hereditas, 122: 67-72.

Belay G, Tefera H, Tadesse B, Metaferia G, Jarra D, Tadesse T. 2006. Participatory Variety Selection in the Ethiopian Cereal Tef (Eragrostis Tef). Experimental Agriculture, 42: 91.

Berhanu K. 1986. A review of weed control research activities on tef in Ethiopia. In Proceedings of the First Ethiopian Crop Protection Symposium, Addis Ababa (Ethiopia), 4-7 Feb 1986. IAR.

Bultosa G. 2007. Physicochemical characteristics of grain and flour in 13 tef [Eragrostis tef (Zucc.) Trotter] grain varieties. Journal of Applied Sciences Research, 3: 2042-2050.

Bultosa G, Taylor JRN. 2004. Teff. Encyclopedia of grain science, 3: 281-290.

Cannarozzi G, Plaza-Wüthrich S, Esfeld K, Larti S, Wilson YS, Girma D, de Castro E, Chanyalew S, Blösch R, Farinelli L, Lyons E. 2014. Genome and transcriptome sequencing identifies breeding targets in the orphan crop tef (Eragrostis tef). BMC genomics, 15: 581. 
Cheverton MR, Chapman GP. 1989. Ethiopian tef: A cereal confined to its centre of variability. In: Wickens GE, Haq N, Day P (eds.) New Crops for Food and Industry. Chapman and Hall, New York, pp: 235-238.

Conert HJ. 1992. Eragrostoideae. in Hegi G (Ed.) Illustriert Flora von Mittel-Europa. Band. I, Vol. 3. Spermatophyta: Angiospermae: Monocotyledones 1(2) Poaceae (Parey Buchverlag: Berlin). Pp. 75-120.

Crymes AR. 2015. The International Footprint of Teff: Resurgence of an Ancient Ethiopian Grain. Arts \& Sciences, Electronic Theses and Dissertations, 394.

Debelo A. 1992. Germination, Yield, and Yield Components of Tef (Eragrostis Tef (Zucc.) Trotter) as Affected by Environment, Tillage and Weed Control Practices (Doctoral dissertation, Oklahoma State University).

Ebba T. 1969. Tef (Eragrostis tef). The Cultivation, Usage and Some of its Known Diseases and Insect Pests. Part I. Expt. Sta. Bull. No. 66. Haile Sellassie I Univesity (HSIU), College of Agriculture, Dire Dawa, Ethiopia.

Evert S, Staggenborg S, Olson BLS. 2009. Soil temperature and planting depth effects on tef emergence. Journal of Agronomy and Crop Science, 195: 232-236.

Fardet A, Leenhardt F, Lioger D, Scalbert A, Rémésy C. 2006. Parameters controlling the glycaemic response to breads. Nutrition Research Reviews, 19: 18-25.

Gebremariam MM, Zarnkow M, Becker T. 2012. Teff (Eragrostis tef) as a raw material for malting, brewing and manufacturing of gluten-free foods and beverages: A review. Journal of Food Science and Technology, 51: 2881-2895.

Gebremedhin T. 1987. The control of red tef worm, in Ethiopia. Trop Pest Manage. London: Taylor \& Francis. Apr/June 1987 33: 170-172.

Georgie MK. 2011. Long-term brain and behavioral consequences of early iron deficiency. Nutrition reviews, 69: S43-8.

Harris P, Geor RJ. 2009. Primer on Dietary Carbohydrates and Utility of the Glycemic Index in Equine Nutrition. Veterinary Clinics of North America - Equine Practice, 25: 23-37.

Hopman E, Dekking L, Blokland ML, Wuisman M, Zuijderduin W, Koning F, Schweizer J. 2008. Tef in the diet of celiac patients in The Netherlands. Scandinavian journal of gastroenterology, 43: 277282.

Hunter M, Barney P, Kilcer T, Cherney J, Lawrence J, Ketterings Q. 2007. Teff as emergency forage. Cornell Univ.Coop.Ext., Agronomy Fact Sheet, 24.

Ingram AL, Doyle JJ. 2003. The origin and evolution of Eragrostis tef (Poaceae) and related polyploids: Evidence from nuclear waxy and plastid rps16. American Journal of Botany, 90: 116-122.

Jackman N.D. 1999. Tef and finger millet, archaeobotanical studies of two indigenous East
African cereals (Doctoral dissertation, Simon Fraser University).

Jansen GR, Dimailo LR, Hause NL. 1962. Amino acid composition and lysine supplementation of teff. Journal of Agricultural and Food Chemistry, 10:6264.

Kaplan M, Üke Ö, Kale H, Yavuz S, Kurt Ö, Atalay Aİ. 2016. Olgunlaşma Döneminin Teff Otunun Potansiyel Besleme Değeri, Gaz ve Metan Üretimine Etkisi. Iğdır Üni. Fen Bilimleri Enst. Der. / Iğdır Univ. J. Inst. Sci. \& Tech., 6: 181-186.

Ketema S. 1993. Tef (Eragrostis tef): breeding, agronomy, genetic resources, utilization, and role in Ethiopian agriculture.

Ketema, S. 1997. Tef. Eragrostis tef (Zucc.) Trotter. Promoting the conservation and use of underutilized and neglected crops. Vol. 12 Institute of plant genetics and crop plant research, Gatersleben/International Plant Genetic Resources Institute, Rome, Italy.

Kreitschitz A, Tadele Z, Gola EM. 2009. Slime cells on the surface of Eragrostis seeds maintain a level of moisture around the grain to enhance germination. Seed Science Research, 19: 27-35.

Watson L, Macfarlane TD, Dallwitz MJD. 1992. Grass genera of the world-introduction. CAB international.

Miller D. 2010. Teff grass: crop overview and forage production guide. Cal/West Seed Company. Woodland, CA 95695.

Mosi AK, Butterworth MH. 1985. The voluntary intake and digestibility of combinations of cereal crop residues and legume hay for sheep. Animal Feed Science and Technology, 12: 241-251.

National Academy of Sciences. 1996. Lost Crops of Africa. National Academies Press.

Refera A. 2001. TEF: Post-harvest operations. Addis Ababa, Ethiopia: Institute of Agricultural Research Organization, Holetta Agricultural Research Center (IARO)

Roseberg RJ, Norberg S, Smith J, Charlton B, Rykbost K, Shock C. 2005. Yield and quality of teff forage as a function of varying rates of applied irrigation and nitrogen. Klamath Experiment Station, 1069: 119136.

Stallknecht GF, Gilbertson KM, Eckhoff JL. 1993. Teff: Food Crop for Humans and Animals. New crops.Wiley, New York, 5: 231-234.

Stewart RB, Yiroou D. 1967. Index of plant diseases in Ethiopia. Bull.Exp.Stn Coll.Agric.Halle Selassie Univ. 30.

Tadesse D, Kebede H. 1995. Germplasm collection, conservation and characterization of tef. Plant Genetic Resources Centre/Ethiopia.Internal Report.Addis Abeba, Ethiopia.

Tareke B. 1981. Inheritance of lemma color, seed color and panicle form among four cultivars of Eragrostis tef (Zucc.) Trotter. PhD thesis, University of Nebraska, Lincoln, Nebraska.

Teegarden D. 2003. Calcium Intake and Reduction in 
Weight or Fat Mass. The Journal of nutrition, 133(1):249-251.

Tefera H, Assefa K, Hundera F, Kefyalew T, Teferra T. 2003. Heritability and genetic advance in recombinant inbred lines of tef (Eragrostis tef). Euphytica, 131: 91-96.

Thompson T. 2000. Folate, iron, and dietary fiber contents of the gluten-free diet. Journal of the American Dietetic Association, 100: 1389-1396.

USDA USDOARS. 2016. National Nutrient Database for Standard Reference, Release 28.

Vinning GS, McMahon G. 2006. Gluten-free Grains: A Demand-and-supply Analysis of Prospects for the Australian Health Grains Industry: a Report for the Rural Industries Research and Development
Corporation. Rural Industries and Development Corporation.

WHO. 2003. Diet, nutrition and the prevention of osteoporosis. Public Health Nutrition, 7: 227-43.

Wolter A, Hager AS, Zannini E, Arendt EK. 2013. In vitro starch digestibility and predicted glycaemic indexes of buckwheat, oat, quinoa, sorghum, teff and commercial gluten-free bread. Journal of Cereal Science, 58: 431436.

Zemel MB. 2003. Role of dietary calcium and dairy products in modulating adiposity. Lipids, 38: 139146.

Zimmermann MB, Hurrell RF. 2007. Nutritional iron deficiency. The Lancet, 370(9586): 511-520. 